\title{
Territorial Impact Assessment - European context and the case of Czechia
}

\section{Štěpán Nosek*}

Charles University, Faculty of Science, Department of Social Geography and Regional Development, Czechia

* Corresponding author: stepan.nosek@gmail.com

\begin{abstract}
The aim of this paper is to critically review recent EU level debates on territorial impact assessment, which serves as a tool to improve the understanding of uneven territorial impacts of the EU sectoral policies. The paper also seeks to elicit (1) which European countries employ territorial impact assessment when designing various national policies and (2) how this tool is used in different governance environments. Particular attention is paid to the case of Czechia. The paper elaborates upon the state-of-the-art tools used on a national level and analyses the motivation of actors on regional and local levels to use such tools in their decision-making process. The research shows that EU member states that employ this tool can be categorized into four groups, for instance, depending on whether they enrich other impact assessments tools by territorial aspects, or whether they focus coherence of regional development strategies and sectoral strategies. Territorial impact assessment is not implemented in Czechia, although recent years have witnessed an upsurge of interest concerning territorial aspects of investments.
\end{abstract}

\section{KEYWORDS}

Territirorial Impact Assessment; European Union; Czechia

Received: 27 April 2019

Accepted: 4 July 2019

Published online: 20 August 2019

Nosek, Š. (2019): Territorial Impact Assessment - European context and the case of Czechia. AUC Geographica 54(2), 117-128 https://doi.org/10.14712/23361980.2019.1

(C) 2019 The Author. This is an open-access article distributed under the terms of the Creative Commons Attribution License (http://creativecommons.org/licenses/by/4.0). 


\section{Introduction}

For a long time, there has been a quest to understand spatial or territorial consequences of public policies (Nijkamp and Van Pelt 1989). Some public policies are focused directly on increasing the development potential of certain regions (regional policy). Other public policies are not directly focused on regions, but their impact is often greater compared to explicit regional policies. For decades, there have been attempts to develop tools which would enable to assess or to measure a spatial impact of public policies.

In the 1970s, first tools emerged in the USA in order to assess the impact of policies or projects with a focus on environmental and economic impacts (e.g. Caldwell 1988; Bond and Pope 2012; Francis 1975). However, geographers have been traditionally interested in more complex tools assessing all aspects of territorial development. Discussions at the EU level regarding the territorial dimension and territorial cohesion paved the way for more complex tools enabling a holistic approach in the evaluation of impact on territorial development (e.g. Medeiros 2017).

According to Fischer et al. (2015), territorial impact assessment (TIA) is a distinctly EU policy assessment closely connected to the EU territorial cohesion agenda and "does not make much sense in, e.g. the USA where people are used to move to areas of greater economic opportunity" (p. 9). The Territorial Agenda of the European Union 2020 (European Commission 2011) states that territorial cohesion "enables equal opportunities for citizens and enterprises, wherever they are located" (p. 3). Following the addition of territorial cohesion among strategic goals of the European Union in 2009, it seems to be even more important to evaluate potentially uneven territorial impacts of particular projects, strategies, or policies.

Territorial Impact Assessment is a tool which appeared in a practical debate in 1989 with the launch of the European Spatial Development Perspective (ESDP; Zonneveld and Waterhout 2009).

The aims of this paper are twofold: firstly, to critically review recent developments regarding impact assessment tools at the EU level and, secondly, to analyse awareness about these tools and the current state of their implementation in one EU member state - in Czechia. Czechia was selected for a case study due to the fact that the author of this paper has followed the discussion and subsequent application of territorial impact assessment in this country over the past five years. Therefore, the paper seeks primarily to answer these questions:

(Q1) How do European countries deal with the challenge of evaluating territorial impacts of their policies?

(Q2) What is the current state of Territorial Impact Assessment implementation in Czechia?

The paper unfolds as follows: Chapter 2 presents an overview of different types of impact assessment with special attention to TIA. Chapter 3 analyses the current state of the art in selected European countries in using TIA or similar tools. Chapter 4 focuses on Czechia and explains how TIA or similar tools are employed. Chapter 5 summarizes the main conclusions and presents several suggestions for further development of TIA in the Czech context.

From a methodological standpoint, the paper is based mostly on content analysis of available documents dealing with the topic of policy evaluation and (territorial) impact assessment in particular countries. This source of information has been complemented with questionnaires sent to academics and public officials in several countries. The ambition of the study was to elaborate on the current situation in TIA use in all EU countries. Thus, respondents were asked an open question, i.e. to describe use of TIA in particular EU member states. Combination of those two sources (content analysis and questionnaires) enabled to divide EU member states into four categories (see Chapter 3 and Table 2). Nonetheless, relevant information has not been found in case of particular countries.

The analysis concerning Czechia is based on this author's experience gained at the Czech Ministry of Regional Development and at the International Advisory Centre for Municipalities, which implemented impact assessment techniques in the city of Litoměřice.

\section{The Role of Impact Assessment Tools in Policy Coordination}

It is only natural that since the addition of territorial cohesion among the European Union's goals, it has become even more pressing to assess territorial impacts of sectoral policies that do not explicitly follow regional policy goals - no matter what the goals of particular regional policies in different national contexts are, the Territorial Impact Assessment methodology has been developed as a tool to measure potential territorial effects of sectoral policies (Golobič and Marot 2011).

TIA might be understood as a new addition to a vast array of impact assessment tools that have been applied since the 1970s. Impact assessment, which is mostly used and embedded in legislation of many countries all over the world focuses primarily on economic and environmental dimensions (see Table 1). However, proper evaluation of impacts on territorial development should include other dimensions as well. Stutz and Warf (2012) state that, "in conventional usage development is a synonym for economic growth" (p. 268). Nevertheless, territorial development should be understood in a more complex way, Medeiros (2017) concludes that territorial development should follow five main goals: economic competitiveness, social cohesion, environmental 
Tab. 1 Types of Impact Assessment.

\begin{tabular}{|l|l|l|l|l|}
\hline \multirow{2}{*}{} & \multicolumn{3}{|c|}{ Impact assessment focused on } \\
\cline { 2 - 5 } & \multicolumn{1}{|c|}{ Economic dimension } & \multicolumn{1}{|c|}{ Environmental dimension } & \multicolumn{1}{c|}{ Social dimension } \\
\hline Examples & $\begin{array}{l}\text { Cost-benefit analysis } \\
\text { Regulatory Impact } \\
\text { Assessment }\end{array}$ & $\begin{array}{l}\text { Environmental Impact } \\
\text { Assessment } \\
\text { Strategic Impact } \\
\text { Assessment }\end{array}$ & Poverty Impact Assessment & Territorial Impact Assessment \\
\hline
\end{tabular}

Source: Author

sustainability, sound processes of territorial governance, and efficient processes of spatial planning or territorial articulation. TIA is then supposed to encompass all those dimensions.

\subsection{Impact assessment - definition and origins}

The purpose of impact assessment is to assess potential impacts of certain actions before they are implemented (Hayes 2017). Impact assessment is thus supposed to evaluate what might happen as a direct consequence of a particular project, strategy, or a policy. Today, there are more than 40 types of IA discussed in literature (Morrison-Saunders et al. 2014). The most frequently used ones are Environmental Impact Assessments, Strategic Environmental Impact Assessment, or Regulatory Impact Assessments, which are embedded in law in most of countries.

The first impact assessments focused on environmental impacts: the first legally binding IA was the Environmental Impact Statement (EIS), which came into force on January 1, 1970 in the USA (Bond and Pope 2012). This tool was aimed at federal actions that might significantly affect the quality of human environment (Francis 1975). At first, the tool was used for large projects such as dams or nuclear power plants but it was also used for assessment of smaller projects in urban environment relatively soon (Francis 1975).

The system of impact analysis in the United States was strengthened in the 1980s, when the Urban and Community Impact Analysis (UCIA) was developed as a consequence of Jimmy Carter's presidential campaign promise to develop the first explicit urban policy. The main aim of the impact assessment program was to ensure that there will be no actions contradicting the urban policy (Hack and Langendorf 1980).

Glickman (1980) summarizes the methodology as being focused on assessing policies rather than projects and being focused on places rather than people UCIA was being focused on assessing macroeconomic impacts. Evers (2011) understands the Urban Impact Analysis as a clear predecessor to the TIA, since "it sought to assess the impact of non-urban policies (regional, local or even international) on urban areas" (p. 8).

The implementation of the Urban Impact Analysis sparked a debate concerning potential unintended spatial effects of public policies. With the exception of the United States, there were no impact analyses or assessments embedded in the law in other advanced countries. However, according to Nijkamp and Van Pelt (1989), the OECD collected a number of case studies of urban impact analyses in Sweden, Canada, or France.

In the late 1980s, the term strategic environmental assessment was coined in an interim report to the European Commission (Fungisland Tetlow and Hanusch 2012). Strategic environmental assessment of policies and strategies has been clearly developed upon the practice of Environmental Impact Assessment (EIA) focused on the level of projects. However, whereas EIA is primarily concerned with how a certain proposed development could affect the environment, Strategic Environmental Assessment (SEA) was also supposed to analyse potential effects of alternative developments early in the decision-making process (Fungisland Tetlow and Hanusch 2012).

\subsection{Territorial Impact Assessment of projects, policies and future trends}

Since the addition of territorial cohesion among the goals of the European Union in 2009, the importance of evaluating potential territorial impacts of policies, strategies or particular projects became yet more relevant, at least in the European context. Nevertheless, policy-evaluation tools were developed already in 1980s as an integral part of the Structural Funds intervention process (Medeiros 2017). Between 1995 and 1999, the European Commission (EC) produced a detailed evaluation methodology under the MEANS programme, which inter alia clearly distinguished between "results" and "impacts". The first one connected to direct measurable consequences, the latter focused on long-term consequences. Medeiros (2017) analysed "the MEANS collection" and concluded that "the notion of territorial impacts is entirely absent" and that "no concrete references are made to the need for a more holistic impact assessment" (p. 149).

Another set of documents dealing with TIA were the outcomes stemming from the EVALSED programme concluded in 2008 (updated in 2013). According to Medeiros (2017), EVALSED took territorial dimension of policy evaluation more into account.

The European Commission released its first Impact Assessment (IA) guidelines only in 2005. Surprisingly, the guidelines did not include any reference to "territorial impacts"; instead they have focused on the 
assessment of economic, social, and environmental impacts in a way that is complementary to SEA, and EIA (Tscherning, König, Birthe, Helming and Sieber 2007). At the same time, during public consultation to the IA procedure, the EC published guidelines to assess regional and local impacts, which could be considered as the first EC attempt to establish a TIA procedure (Medeiros 2017).

As a result of all these programs and activities, the awareness about TIA, at least on the European level, was growing. The European Commission document "Investing in Europe's Future - Fifth Report on Economic Social and Territorial Cohesion" included a statement that "both policies with and without an explicit spatial dimension could benefit from an assessment of territorial impact" (European Commission 2010, p. 195).

However, at the beginning (in the 1990s and the 2000s), TIA was conceived rather as an ex-post assessment tool of the EU policies such as the Common Agricultural Policy or Transport and Trans-European Network Policies and was based on quantitative models (Fischer et al. 2015).

The European Spatial Development Perspective Action Plan adopted in Tampere in 1999 defined the development of a TIA methodology as one of key tasks for the European Spatial Planning Observation Network (ESPON) (Fischer et al. 2015). ESPON enabled to involve experts in the field of TIA and subsequently to support numerous research projects. Thus, it was the ESPON programme (established in 2002) that triggered the development of first rigorous TIA methodologies. According to Medeiros (2017), the ESPON programme funded more than 20 analyses dedicated to the identification of impact of EU sectoral policies, but only a few of them could be regarded as TIA tools. Fischer et al. (2015) divide ESPON methodologies into several period which demonstrates gradual shift of TIA design.

First period (2004-2006) was characterized by use of quantitative models and ex-post assessment of particular European policies (e.g. Common Agricultural Policy). During this period for instance STIMA (Spatial Telecommunications IMpact Assessment) methodology has been established (see ESPON 2004).

Methodologies prepared in second period (20082010) were still based on quantitative models, but focused mostly on ex-ante assessment. This was the case for instance for TEQUILA tool/model which included all dimensions and components of the concept of territorial cohesion (Medeiros 2017), but the results were difficult to read (Medeiros 2017). Specific was ARTS methodology which admitted use of qualitative models and more participatory approach.

Third period (since 2012) is connected especially with EATIA methodology which brings significant simplification of TIA procedure and use of qualitative methods. EATIA is still based on ex-ante assessment. Another step in a quest for simplification was the introduction of the TIA Quick Check Tool. This interactive web-based tool was introduced by ESPON in 2015 and enables to measure territorial impacts at the level of the NUTS 3 regions. The TIA Quick Check Tool Is based on the ESPON ARTS methodology and was prepared by the Austrian Institute for Spatial Planning. However, according to Medeiros (2017), the TIA quick check tool is too simplified and does not include all crucial components of territorial impact evaluation. Medeiros (2017) calls for a more robust (and relevant) evaluation technique, despite the fact that such techniques demand more resources and time.

Overall, one can argue that TIA moved from a tool to be used for assessment of territorial impact of projects (Austria, Germany) to a tool used for evaluation of potential territorial impacts of policies. There have been even efforts to analyse territorial impacts of future trends (for instance Böhme and Lüer 2017).

Broadly speaking, the methodology of TIA is similar to those of EIA and SEA, or other impact assessment tools. All of these methodologies "explore the causal links between proposed actions and impacts" (Perdicoulis et al. 2016, p. 42). EIA, SEA, or Cost Benefit Analyses (CBA) methodologies can be considered as prescriptive regarding which procedures should be followed and which aspects should be addressed (Fischer et al., 2015). TIA, on the other hand, is supposed to be more holistic, and should also take into account governance arrangements. According to Evers (2011), the emergence of TIA methodology has also been caused by the need "to gain information on policy effects within an increasingly fragmented public sector" (p. 76).

Medeiros (2017) sees TIA as a tool with a significant potential to replace the EIA and SEA, since all existing TIA methodologies take into account the environmental dimension. However, it might be a challenging task, given the path-dependency of public policies. Consequently, when compared to its predecessors focusing on impacts in a narrow sense (EIA, SEA, CBA), TIA enables to evaluate a potential impact in a more complex way (Evers 2011).

Medeiros (2014) summarizes briefly all impact assessment tools and concludes that TIA is "the most difficult and complete IA procedure, since it needs to take into consideration all the aspects of territorial development (socio-economic, environmental, governance and spatial organization)" (p. 198). However, according to Medeiros (2015), the territorial development does not equal the sum of socio-economic and environmental impacts. Medeiros (2018 and 2019) also suggests to apply TIA to evaluate spatial planning processes and (Medeiros 2019) and sectoral policies, for instance cross-border cooperation (Medeiros 2018).

According to Medeiros (2015), the economic dimension of policy evaluation has always been omnipresent because of the "strong position of economists in this particular scientific field of policy evaluation". Medeiros (2015, p. 9) also explains that complex IA 
tools started to be tested after some of the EU strategic documents explicitly recognized the "territorial dimension as a key element of policy intervention". Medeiros (2015, p. 9) suggests that there is a mainstream vision that policies should contribute primarily to the economic development. Nevertheless, he calls for a more holistic approach that would take into account several other dimensions of development such as social cohesion, environmental sustainability, territorial governance and spatial planning. Similarly, Zonneveld and Waterhout (2009) argue that TIA "has to focus on the impact of policy and contextual developments on the spatial organization and spatial position of spaces and places" (p. 3).

\section{TIA implementation in EU member states}

TIA at the EU level certainly represents a valuable tool that helps to understand unintended territorial impacts of EU policies or new legislature. Nevertheless, such a tool at the EU-level cannot reflect all specificities at the national, regional, or local levels. Therefore, TIA at the EU level should be followed by national TIAs (Zonneveld and Waterhout 2009). However, according to Medeiros (2017), no EU member state or other country has encoded a mandatory use of TIA. Consequently, the TIA procedures could be labelled as an "EU experiment" (Medeiros 2017).

In European countries, different techniques are employed to ensure that sectoral (non-regional) interventions are in line with the principles of regional policy (no matter how defined). Obviously, numerous factors, including the governance system, administrative cultures, and political settings, influence the way (territorial) impact assessment is implemented (Meuleman 2015). Meuleman (2015) suggests that the governance approach may vary: it can be more market-driven in Anglo-Saxon countries, more network-driven in northwest Europe, and more hierarchical in Central, Eastern, and Southern Europe. Each governance system implies certain weaknesses, such as prioritization of efficiency in a market-driven model, the risk of losing focus in a network-driven approach, or rigidity in the hierarchical model (Meuleman 2015).

Within the EATIA project, there were some, albeit limited, efforts to disseminate the European TIA methodology to particular EU member states (Slovenia, Portugal, the United Kingdom) (Fischer et al. 2015). One of the conclusions stemming from the dissemination of results was a suggestion that the TIA concept is flexible enough to be adaptable to different policy-making traditions (Fischer et al. 2015). Although Slovenian (e.g. Golobic and Marot 2011) and Portuguese (e.g. Medeiros 2015) academics contributed significantly to the research in the field of TIA, both in Slovenia and Portugal TIA procedures are still rather unknown concept (Marot 2015; Medeiros 2015).
Regarding TIA implementation EU countries could be distinguished into several categories which are not mutually exclusive. First category consists of German speaking countries (chapter 3.1). Second category represents countries where focus on compliance with regional or sustainable development strategy is required when sectoral policies are designed (chapter 3.2). Countries in third category (chapter 3.3.) enrich traditional impact assessment tools by territorial aspects. Countries in fourth category (chapter 3.4) elaborate Territorial Impact Assessment ad-hoc in order to assess impact assessment of large projects, or European directives/policies.

\subsection{TIA as a traditional tool in German speaking countries}

Tools similar to TIA are used traditionally mostly in German-speaking countries. The roots of TIA can be traced back to tools used traditionally in Austria, Germany, and Switzerland. Even the fact that the term territorial impact assessment is directly translated from its German equivalent demonstrates that the roots of the tool can be traced in the German-speaking world (Othengrafen and Cornett 2013; Healy 2001). In Austria and Germany, TIA is used extensively for ex-ante evaluation of major projects.

Particularly in Austria, the use of TIA can be traced back to 1959 , thus even predating the introduction of EIA (Healy 2001). In German-speaking countries, competences of different levels of public administration (national, regional, and local) are set out very clearly (Tosics et al. 2010). This holds true for spatial planning as well. According to Tosics et al. (2010), the federal systems of Germanic countries result in a strong regional level of planning.

Particular authors even declare that TIA is embedded in Austrian, German, or Swiss Law (e.g. Zonneveld and Waterhout 2009). This was, nevertheless, dismissed by Dallhammer (2016) who argues that "Raumverträglichkeitsprüfung" (which is a tool sharing similarities with TIA) is proceeded on voluntary basis and only in particular federal states (e.g. Carinthia).

Paradoxically, Austria does not have a very strong explicit regional policy (Polvevari and Michie 2011). The Austrian Conference on Spatial Planning has been established only in 1971 in order to enhance cross-sectoral coordination. The body comprises representatives of the state (Bund), federal states (Länder), and municipalities. Each ten years the Austrian Spatial Development Concept is adopted to coordinate federal policies with spatial impact and policies implemented by Länder (Polvevari and Michie 2011). Similarly, in Germany, sectoral policies are coordinated through the Regional Joint Task (Polvevari and Michie 2011).

Germany evaluates ex-ante impacts of transport infrastructure or large retail projects "to verify whether these are in line with the aims and objectives 
of official planning policies" (Othengrafen and Cornett 2013, p. 13). The process (called Raumordnungsverfahren) usually takes around three months. According to Healy (2001), the German procedure is focused on testing the conformity of new projects and new regional plans with existing plans. Bundesländers (sixteen units) are in charge of this process.

\subsection{TIA as tool to align territorial priorities with sectoral and regional strategies}

Such strategy is relevant for instance for Switzerland, where Sustainable Development Strategy 2016-2019 states that the implementation of the document is coordinated by the interdepartmental Sustainable Development Committee, which is supposed to ensure the incorporation of sustainable development principles into sectoral policies (Swiss Federal Council 2016).

Similar strategies are employed in Ireland, where the compliance of strategies at both local and regional levels with the Irish National Spatial Strategy is a key requirement (Hague 2010), and in Estonia (Ministry of Regional Development 2018) where compliance with the most important elements of the Estonian Regional Development Strategy for 2014-2020 is assessed while preparing new regulations, strategic policy documents, and grant schemes supported by the EU Structural Funds.

In Poland specific document entitled Territorial dimension of strategic documents have been prepared in order to bridge the gap between territorial and sectoral strategic documents (Szlachta, Zaucha and Komornicki 2017). Similar tool with focus on operational programmes have been invoked in Czechia (see chapter 4).

\subsection{TIA as an enrichment of traditionally used tools}

This strategy is relevant for Finland, Belgium, or Denmark. Those countries use standard EIA, SEA, or Regulatory Impact Assessment (RIA) procedures and "upgrade" them, at least in some cases in order to assess wider development processes. Finnish EIA aims to evaluate not only the impact on human health and environmental aspects (soil, water, air, climate etc.), but also the impact on "the urban structure, buildings, landscape, townscape and cultural heritage". (Ministry of Environment Finland 2009). Similarly, in Wallonia the EIA procedure was adjusted in order to encompass certain aspects of TIA (Hague 2001; Böhme and Lüer 2017). Denmark held discussions regarding a holistic approach within the EIA procedure currently, as well (Kørnøv, Christensen and Nielsen 2005). In another cases the RIA is "upgraded". This is the case for Belgium and its Flemish Region, where RIA includes the Sustainable Development Impact Assessment (OECD 2010; Huge and Waas 2011).

The United Kingdom has specific impact assessment called rural proofing, which evaluates potential impacts on rural areas (Hague 2010). Rural proofing evaluates impacts on services, infrastructure, business, employment, environment etc. (Department for Environment, Food and Rural Affairs 2017). In 2011, IA Toolkit was published by the Department for Business, Innovation and Skills (2011). In the British context, IA is based mostly on a cost-benefit analysis. The use of impact assessments in the United Kingdom has been discussed in connection with Brexit, but no impact assessment of Brexit has been conducted so far. This was later criticized by Fischer and Sykes (2017), who suggested that impact assessment taking into account not just economic impact but a wider scale of impact should be conducted in case of Brexit, because it is clear that it is going to have uneven regional impacts.

\subsection{Ad-hoc use of TIA}

Such TIAs were applied in Netherlands, Poland, or Lithuania. In the Netherlands, there is no standard TIA procedure. Large projects are usually assessed via a cost-benefit analysis. Currently, there are efforts to include a social dimension via a social cost-benefit analysis (Evers 2016). Nonetheless, the Netherlands experienced an ad-hoc implementation of TIA in connection with possible regional implications of the EU's policies. According to Evers (2011), the Dutch Ministry of Housing, Spatial Planning and the Environment requested the Environmental Assessment Agency to conduct TIA as a reaction to the European territorial cohesion policy and to the energy-climate package. Evers (2011) stresses that "given the two very different points of the policy process, the studies are very different in character in terms of methodology and conclusions" (p. 98). The TIA focusing on the European territorial cohesion policy was affected by not having a clear definition of territorial cohesion. In contrast, the energy-climate package had clearly stipulated goals and it was thus ambition of TIA to find policy actions in order to meet targets. Ad hoc impact assessments are undertaken as well for large projects (Poland), or after implementation of the EU programming period (Lithuania).

\section{Summary}

Table 2 shows that there is a rather limited use of Territorial Impact Assessment or similar tools across European countries. Nevertheless, according to several studies (e.g. Dabrowski 2012; Raagmaa and Stead 2015), a certain trend towards Europeanization of public policies can be observed especially in Central and Eastern Europe, especially in the fields of spatial planning and regional policy. This might be seen, for instance, in Partnership Agreements signed between the European Commission and particular member states, which include an analysis of tools to be used by the member states to enhance the territorial approach 
Tab. 2 Typology of TIA use in EU member states and Switzerland.

\begin{tabular}{|l|l|l|}
\hline \multicolumn{1}{|c|}{ Type of TIA use } & \multicolumn{1}{|c|}{ Description } & Countries \\
\hline TIA encoded in the law & $\begin{array}{l}\text { TIA used extensively for ex-ante impact } \\
\text { assessment of large infrastructure projects }\end{array}$ & Germany, Austria \\
\hline $\begin{array}{l}\text { TIA as tool to align of territorial priorities } \\
\text { with sectoral and regional strategies }\end{array}$ & $\begin{array}{l}\text { Compliance of policies, plans, or strategies } \\
\text { compared with main regional development } \\
\text { strategies }\end{array}$ & Estonia, Ireland, Switzerland, Poland \\
\hline $\begin{array}{l}\text { TIA as an enrichment of traditionally used } \\
\text { tools }\end{array}$ & $\begin{array}{l}\text { Territorial aspects more or less incorporated } \\
\text { into existing evaluation techniques }\end{array}$ & Belgium, Finland, Greece, Denmark, Great Britain \\
\hline Ad-hoc TIA & $\begin{array}{l}\text { TIA used "when needed" such as before } \\
\text { implementation of European directives and } \\
\text { policies into national contexts }\end{array}$ & Netherlands \\
\hline No TIA procedure & $\begin{array}{l}\text { Mostly Central and European countries } \\
\text { declare no use of standard TIA procedures }\end{array}$ & $\begin{array}{l}\text { Slovakia, Slovenia, Hungary, Lithuania, Latvia, } \\
\text { Romania, Bulgaria, Croatia, Czechia, Portugal }\end{array}$ \\
\hline No relevant information founded & $\begin{array}{l}\text { During desk research no relevant information } \\
\text { regarding TIA in seven EU countries has been } \\
\text { found }\end{array}$ & $\begin{array}{l}\text { Sweden, Malta, Cyprus, Spain, Italy, France, } \\
\text { Luxembourg }\end{array}$ \\
\hline
\end{tabular}

Source: Author

in implementation of the EU cohesion policy (Nosek 2017).

The position of (spatial) planning in Central and Eastern European countries in the 1990s was difficult, mostly because planning of any kind was associated with the communist regime by both policy-makers and population in general (Raagmaa and Stead 2015).

There is no doubt that an EU membership pushes member states to adopt changes in the strategic planning process (Dabrowski 2012), including an application of more sophisticated methods in impact assessment. Therefore, it can be expected that some sort of mapping of territorial impact will become more embedded in spatial planning processes in the near future.

Namely, some Central and Eastern European countries plan to apply impact assessments tools over the next few years. This is the case, for instance, in Romania, which expects that the methodology for measuring territorial impact of sectoral policies will be approved by the Government following the approval of the Territorial Development Strategy (Ministry of Regional Development 2018).

\section{The case of Czechia}

According to the law defining responsibilities of particular Czech ministries, the Ministry of Regional Development is obliged to coordinate other ministries in order to implement regional policy. Such setting might seem favourable for pushing sectoral ministries to reflect regional specifics.

Nonetheless, the actual promotion of regional aspects into sectoral strategies and policy-making process cannot be taken for granted. Such promotion demands numerous discussions and eventually also political support - which is in Czech context frequently lacking. The Ministry of Regional Development is often considered less influential in comparison with Ministry of Industry and Trade or Ministry of Environment. As a consequence, certain ministries see the territorial dimension concept as a threat and intervention into its competencies.

Czechia is one of the countries which do not use TIA methodology at the national level. However, an interest in the tool has been growing in recent years, similarly to other Central and Eastern European countries and certain measures have been taken to adjust sectoral policies in order to reflect territorial specificities.

\subsection{TIA at the policy level in 2014-2020 programming period}

According to the Partnership Agreement between the European Commission and Czechia concluded in 2014 , the territorial dimension is in the Czech context understood as a possibility to concentrate resources from the European Structural and Investments Funds (ESIF) in specific types of territories supporting both competitiveness and moderating territorial disparities (social, economic, environmental).

In Czechia, a relatively comprehensive approach to incorporate the territorial dimension into the programmes within the period 2014-2020 was developed. In particular, a special document called the National Document for Territorial Dimension (NDTD; Ministry of Regional Development 2015) was prepared with the aim to identify, which specific goals should be preferred in specific types of territories.

The incentive for its existence came implicitly from the European Commission, which pushed for more territorially sensitive implementation of European Structural and Investment Funds. This document also served as a "substitute" for Czech NUTS II regions which implemented its own regional operational programmes in 2007-2013 programming period. 
Overall, eight types of specific territories have been identified in the NDTD (e.g. for urban areas, for rural areas, for socially excluded localities, for solving labour market problems, for enhancement of entrepreneurship etc.).

NDTD could be understood as a kind of ex-ante TIA. This document indicates which measures will most likely have uneven territorial impacts, similarly to concepts described in the previous chapter and applied by ESPON or by particular countries (e.g. Austria or Germany). However, in contrast to ESPON models, in Czechia, no data analysis has been performed in order to decide which specific goals should have the territorial dimension.

The NDTD also specifies the volume of funds that the state will distribute via the territorial dimension. Resources used for addressing the territorial dimension include funds distributed through tools designed to support urban development (i.e. Integrated Territorial Investments and Integrated Territorial Development Plans) and tools aimed at rural development (Community-led Local Development). The total allocation is expected to be approximately 8 billion EUR, which is almost one third of the Czech allocation from the EU European Structural and Investment Funds.

The very existence of the NDTD might be seen as progress in promoting the territorial dimension into sectoral policy making. However, the NDTD was the first document of its kind implemented in Czechia and suffers from several weaknesses. The NDTD was arguably created too late, since it was finalized well after the finalization of operational programmes. Territorial dimension was thus not implemented into the operational programmes, but it was described ex-post, based on discussion with responsible ministries/managing authorities.

The NDTD does not cover national grant schemes and currently, there is no alternative document stipulating the territorial dimension within national grant schemes or national sectoral policies. For example, even the Regional Development Strategy 2014-2020 does not stipulate how sectoral policies are supposed to reflect territorial specificities. The Czech Regional Development Strategy only identifies micro-regions of 57 municipalities with extended powers as "economically weak" and without any further specification states that these micro-regions should be taken into account within sectoral policies.

Each year, progress evaluation in implementation of the NDTD is to be prepared. This evaluation should be primarily based on an analysis of particular calls for proposal and on an analysis of allocation of funds. So far, evaluation has been prepared for years 2015,2016 , and 2017. According to the evaluations for the period 2015-2017, the calls were in most cases targeted at territories specified by the NDTD. Analyses of spatial distribution of allocation of funds have been limited by poor quality of available databases, in which a large proportion of projects did not include information concerning their localization at the municipal level. Nonetheless, available data suggest that the share of the Cohesion policy expected by NDTD to be spend on the territorial dimension has been achieved.

The analysis of individual calls for proposals raised several important questions. First, the pivotal question was which calls should be declared as taking into account the territorial dimension. The NDTD did not include any rigorous methodology in order to assess calls with regard to its territorial dimension. Eventually, four types of possible scenarios have been identified by the Ministry of Regional Development:

- The call is focused exclusively on a specific territory (for instance, on a selected NUTS 2 region).

Tab. 3 Territorial dimension in operational programmes in Czechia in 2014-2020.

\begin{tabular}{|c|c|c|}
\hline Operational Programme & $\begin{array}{l}\text { Level of Territorial } \\
\text { Dimension }\end{array}$ & Description of Territorial Dimension \\
\hline Integrated Regional OP & High & $\begin{array}{l}\text { Specific calls for certain type of regions (e.g. regions with socially excluded } \\
\text { localities); Funds in certain calls distributed in accordance with regional } \\
\text { needs. }\end{array}$ \\
\hline $\begin{array}{l}\text { OP Entrepreneurship and Innovation for } \\
\text { Competitiveness }\end{array}$ & High & $\begin{array}{l}\text { Regions with high unemployment rate or economically weak regions } \\
\text { benefited in selection process. }\end{array}$ \\
\hline OP Transport & Medium & $\begin{array}{l}\text { Projects contributing to regional development priorities supported } \\
\text { primarily. }\end{array}$ \\
\hline Rural Development Programme & Medium & $\begin{array}{l}\text { Most of the activities within Community-led Local Development financed via } \\
\text { Rural Development Programme. }\end{array}$ \\
\hline OP Research, Innovation and Education & Medium & $\begin{array}{l}\text { Local and regional action plans in education define local/regional priorities } \\
\text { in elementary schools and high schools. }\end{array}$ \\
\hline OP Environment & Low & $\begin{array}{l}\text { In certain cases specific territorial dimension applied - for instance localities } \\
\text { specified in flood plans. }\end{array}$ \\
\hline OP Employment & Low & Except of labour market policy. \\
\hline OP Prague - Growth pole & Not Relevant & Focused only on the Capital City of Prague. \\
\hline
\end{tabular}


- The call explicitly declares the distribution of funds among a specific type of regions/municipalities.

- The call sets up the criteria favouring particular regions (e.g. those with an above-average rate of unemployment).

- The call is focused on addressing specific problems that are concentrated in certain regions/territories (i.e. implicit territorial dimension).

When applying such criteria, it appeared that most calls that were expected to have a territorial dimension indeed incorporated it in one way or another into the calls' designs.

The Ministry of Regional Development itself manages in 2014-2020 programming period Integrated Regional Development Programme, which is seen as a flagship programme for regions and cities. Certain important aspects of regional development were however implemented by other (sectoral) ministries, as well.

Table 3 summarizes operational programmes implemented in 2014-2020 programming period and territorial dimension expected by National Document for Territorial Dimension.

\subsection{Territorial dimension expectations in post-2020 period}

Discussions regarding implementation of post-2020 programming period are already underway. Following significant growth of Czech economy in recent years, large decrease of European funds allocation in Czechia is expected in post-2020 period. Thus, the Regional Development Strategy post-2020 aims to define the territorial dimension within particular national sectoral policies in addition to the territorial dimension embedded in operational programmes supported via the European Structural and Investment Funds.

Discussion with bodies responsible for sectoral policies again shows scepticism of sectoral ministries regarding the role of Ministry of Regional Development. Promotion of regionally sensitive policies is often understood as a unnecessary intervention which put artificial element into the policy-making process.

Regional Development Strategy post-2020 aims to elaborate only topics with identified territorial dimension and is supposed to be more specific with comparison to its predecessor. Thus, key questions appearing during most of the discussions are: (1) which topics have territorial dimension (i.e. needs territorially sensitive solutions), and for those which have, (2) how it can be defined in particular fields? Apparently, the debate is often affected by conflicting motivations of particular stakeholders. While representatives of rural areas, cities and regions have a tendency to promote territoriality as much as possible, ministerial officers tend to declare that certain fields (and respective policies) are spatially blind and no significant regional adjustments are needed.
It might be argued that "territorial" stakeholders aim to ensure allocation of funds in future policies implementing the strategy. In their understanding, more territoriality equals higher chances to get funded. Ministries, on other hand, aim to avoid, from their point of view, unnecessary intervention into their policies. In such context, the role of Ministry of Regional Development might be seen as of a mediator.

\subsection{TIA at the Project level}

Until 2016, there was no certified TIA methodology in Czechia at the level of projects. Finally, in 2016, the Ministry of Regional Development published project impact assessment methodology prepared in cooperation with regional policy experts. Following the publication of this methodology, the Ministry of Regional Development plans to start a project (to be implemented in 2019-2020) aimed at raising awareness at the methodology and to train public officials who will be implementing the methodology on all hierarchical levels - national, regional, and municipal. There is also a plan to develop a software tool to guide potential users through the methodology.

This TIA methodology has been inspired by similar documents based on the initiative of the European Commission (especially EC 2009), which includes a list of potential impacts that should be taken into account when evaluating possible impacts of EU policies. Therefore, the Czech methodology designed at the project level has been developed on the basis of the EU methodology, which, however, targeted the level of policies.

The TIA procedure is divided into two steps. In the first step, the evaluator must assess overall quality of the project proposal and decide whether the project will have a significant territorial impact or not. The potential impact is evaluated in the following fields: employment, environment, transport, market, quality of life, and public services. The evaluator must also assess what the level of impact is (average, important, and fundamental).

Project proposals that are considered as those with a potential socioeconomic impact are subject to further analysis. The subsequent procedure of the TIA differs based on the scale of the potential impact in the above-listed fields.

Prior to 2016, TIA or similar methodologies were only exceptionally applied in Czech regions and/or municipalities. One of these exceptions was the city of Litoměřice in Northern Bohemia, whose representatives decided to establish a procedure analogical to TIA in order to measure the possible impact of project proposals supported by the city from the economic, social, and environmental point of view. The assessment is undertaken by "Sustainable Development Strategic Team" consisting of the mayor or his/her deputy, members of the department of strategic development and the department of sustainable development, and members of other relevant 
departments (depending on type of the project). The resulting assessment is subsequently presented to the political representation and forms the basis for the decision-making process. This process is similar to the one employed in Austrian Carinthia, as described in Chapter 3. However, city representatives are not obliged to follow recommendations of this assessment.

\section{Conclusions}

Studies in the sphere of regional policy and regional development have emphasized uneven territorial impacts of non-regional public policies for a long time. Over the past two decades, the search for a sophisticated tool that would enable to analyse territorial impacts of proposed interventions has already found several potential solutions.

Nevertheless, the ambitions behind the search for a suitable TIA methodology seem to be conflicting. On the one hand, the tool is supposed to be sophisticated enough to take into account all potential territorial impacts, while, on the other hand, it should be simple enough to serve the purposes of public officials in the sphere of regional development at all levels of public administration. This is hardly realistic. Nevertheless, the paper suggests that the territorial impact assessment is a tool that is developing quite dynamically both at the EU level and at the level of member states.

The process of developing TIA methodologies is still under-researched. The aim of this paper was to contribute to research of TIA via an analysis of the extent and form to which the EU member states implement the TIA methodology within their policy-making processes. Specific attention was paid to the case of Czechia, which recently witnessed an upsurge in the interest of public officials in the TIA methodology at the national level.

The first question posed in this paper was focused on the current state of affairs in European countries regarding the use of Territorial Impact Assessment or a similar tool. It can be concluded that while the European Commission has been a clear leader in developing new (and in the past decade largely simplified) methods of territorial impact assessment, the EU member states have not paid similar attention to measuring territorial impacts despite the recent incorporation of territorial cohesion among the European Union goals. From author's overview follows Germany and Austria lead the way towards sound TIA implementation. Several other countries aim at introducing at least simple methods to measure uneven territorial impacts of public policies (Estonia, Romania). This process might be seen as another proof of Europeanization of public policies in Central and Eastern European countries (Dabrowski 2012; Raagmaa and Stead 2015).
The second question focused solely on the recent development of TIA in Czechia. In this country, in order to encompass the territorial dimension within the operational programmes for the EU 2014-2020 programming period, the National Document for Territorial Dimension has been approved by the government. It is the first document of its kind and, despite some shortcomings, it forced the sectoral ministries to take the territorial dimension into account by one way or another during implementation of operational programmes they are responsible for. Nevertheless, a large variety of interpretations of the term territorial dimension have been observed during the implementation phase of particular operational programmes.

Finally, at the project level, a significant achievement has been recently accomplished in Czechia, as in 2016 a TIA methodology at the project level has been published by the government. This came just in time to assist some more active cities and regions in their attempt to design an impact assessment approach to their own projects. Thus, the recently published TIA methodology can stimulate stakeholders at the local and regional level to deal seriously with uneven territorial impacts of various public interventions. The extent to which this potential to deliver more effective and efficient public policies will be used by local and regional actors remains to be seen

Consequently, a thorough analysis of advances made in the field in various countries should be subject to further research.

\section{References}

Bond A., Pope J. (2012): The state of the art of impact assessment in 2012. Impact Assessment and Project Appraisal 30(1), 1-4, https://doi.org/10.1080/14615517 .2012.669140.

Böhme, K., Doucet, P., Komornicki, T., Zaucha, J., Świątek, D. (2011): How to strengthen the territorial dimension of Europe 2020 and the EU Cohesion Policy. Report based on Territorial Agenda 2020. Retrieved March 1, 2018, http://ec.europa.eu/regional_policy/sources/docgener /studies/pdf/challenges2020/2011_territorial_ dimension_eu2020.pdf.

Böhme, K., Lüer, Ch. (2017): Assessing territorial impacts of future trends. In: Medeiros, E.: Uncovering the Territorial Dimension of European Union Cohesion Policy. Cohesion, Development, Impact Assessment and Cooperation, https://doi.org/10.4324/9781315169743-11.

Caldwell, L. K. (1988): Environmental Impact Analysis (EIA): Origins, Evolution, and Future Directions. Impact Assessment 6(3-4), 75-83, https://doi.org/10.1080 /07349165.1988.9725648.

Dabrowski, M. (2012): Shallow or deep Europeanisation? The uneven impact of EU cohesion policy on the regional and local authorities in Poland. Environment and Planning C: Government and Policy 30(4), 730-745, https://doi.org/10.1068/c1164r.

Dallhammer, E. (2016): Personal communication, 9 February, 2016. 
Department for Business, Innovation and Skills (2011): Impact Assessment Toolkit. Retrieved May 6, 2018, www.legislationline.org/documents/id/16803.

Department for Environment, Food and Rural Affairs (2017): Rural Proofing. Practical guidance to assess impacts of policies on rural areas. Retrieved May 5, 2018, https://www.gov.uk/government/uploads/system /uploads/attachment_data/file/600450/rural-proofing -guidance.pdf.

ESPON (2004): ESPON 2.1.1: Territorial Impact of EU Transport and TEN policies.

ESPON (2013): ESPON ARTS: Assessment of Regional and Territorial Sensitivity. Final Report.

European Commission (2009): Impact Assessment Guidelines. Retrieved April 9, 2018, http://ec.europa.eu /smart-regulation/impact/commission_guidelines /docs/iag_2009_en.pdf.

European Commission (2010): Fifth Report on Economic, Social and Territorial Cohesion - Investing in Europe's future. Retrieved April 8, 2018, http://ec.europa.eu /regional_policy/en/information/publications /reports/2010/fifth-report-on-economic-social-and -territorial-cohesion-investing-in-europe-s-future.

European Commission (2011): Territorial Agenda of the European Union 2020. Retrieved April 7, 2018, http://ec.europa.eu/regional_policy/en/information /publications/communications/2011/territorial -agenda-of-the-european-union-2020.

European Council of Town Planners and Committee on Spatial Development (2001): Proceedings of the one-day conference on Territorial impact assessment 26 October 2001 Louvain-la-Neuve, Belgium. Retrived March 14, 2018, http://www.ectp-ceu.eu/images/stories/download /cp20030515.pdf.

Evers, D. (2011): Territorial Impact Assessment: a critical examination of current practice. PBL Netherlands Environmental Assesment Agency.

Evers. D. (2016): Personal communication, 18, January, 2016.

Hayes, A. C. (2017): What is impact assessment? Some personal reflections C. P. Wolf (1933-2015), edited posthumously by Adrian C. Hayes. Impact Assessment and Project Appraisal 35(3), 186-199, https://doi.org /10.1080/14615517.2017.1322812.

Hague (2010): European Perspectives on Territorial Impact Assessment. A Background paper for the ESPON EATIA Project. Retrieved March 11, 2018, http://www.rtpi.org .uk/media/5994/European-Perspectives-on-Territorial -Impact-Assessment-April-2010.pdf.

Fischer, T. B. (2014): Impact Assessment: there can be strength in diversity! Impact Assessment and Project Appraisal 32(1), 9-10, https://doi.org/10.1080 /14615517.2013.872844.

Fischer, T. B., Sykes, O., Gore, T., Marot, N., Golobič, M., Pinho, P., Waterhout, B., Perdicoulis, A. (2015): Territorial Impact Assessment of European Draft Directives The Emergence of a New Policy Assessment Instrument. European Planning Studies 23(3), 433-451, https://doi .org/10.1080/09654313.2013.868292.

Fischer, T. B., Sykes, O. (2017): Impact Assessments: What Impact Assessments? And what is an Impact Assessment? Retrieved March 10, 2018, https://news .liverpool.ac.uk/2017/12/08/impact-assessments-what -impact-assessments-and-what-is-an-impact-assessment.
Francis, M. (1975): Urban Impact Assessment and Community Involvement: The Case of the John Fitzgerald Kennedy Library. Environment and Behavior 7(3), 373-404, https://doi.org/10.1177/001391657500700307.

Fungisland Tetlow, M., Hanusch, M. (2012): Strategic environmental assessment: the state of the art. Impact Assessment and Project Appraisal 30(1), 15-24, https:// doi.org/10.1080/14615517.2012.666400.

Glickman, N. J. (1980): Urban Impact Analysis: Premises, Promises, Procedures, and Problems. Built Environment 6(2), 84-91.

Golobic, M., Marot, N. (2011): Territorial impact assessment: Integrating territorial aspects in sectoral policies. Evaluation and Program Planning 34, 163-173, https://doi.org/10.1016/j.evalprogplan.2011.02.009.

Hack, G., Langendorf, R. (1980): Lessons from Urban Impact Assessment. Environmental Impact Assessment Review 1(3), 251-266, https://doi.org/10.1016/S0195 -9255(80)80103-X.

Healy, A. (2001): Keywork Phrase: Territorial Impact Assessment. Retrieved June 18, 2017, http://www .esprid.org/keyphrases/30.pdf.

Huge, J., Waas, T. (2011): Converging impact assessment discourses for sustainable development: the case of Flanders, Belgium. Environment, Development, and Sustainability 13(3), 607-626, https://doi.org/10.1007 /s10668-010-9279-z.

Kørnøv, L., Christensen, P., Nielsen, E. H. (2005): Mission impossible: does environmental impact assessment in Denmark secure a holistic approach to the environment? Impact Assessment and Project Appraisal 23(4), 303-314, https://doi.org/10.3152/147154605781765427.

Marot, N. (2015): On the maximal shortest path in a connected component in V2V. Performance Evaluation 94, 25-42, https://doi.org/10.1016/j.peva .2015.09.003.

Medeiros, E. (2014): Assessing territorial impacts of the EU cohesion policy at the regional level: the case of Algarve. Impact Assessment and Project Appraisal 32(3), 198-212, https://doi.org/10.1080/14615517.2014 .915134 .

Medeiros, E. (2015): personal communication, October 8, 2015.

Medeiros, E. (2015): Territorial Impact Assessment and Public Policies: The Case of Portugal and the EU.

Medeiros, E. (2017): From simple to relevant TIA tools for European policies. In: Medeiros, E.: Uncovering The Territorial Dimension of European Union Cohesion Policy. Cohesion, Development, Impact Assessment and Cooperation, https://doi.org/10.4324/9781315169743.

Medeiros E. (2018) Focusing on Cross-Border Territorial Impacts. In: Medeiros E. (eds) European Territorial Cooperation. The Urban Book Series. Springer, Cham, https://doi.org/10.1007/978-3-319-74887-0.

Medeiros, E. (2019) Spatial Planning, Territorial Development and Territorial Impact Assessment. Journal of Planning Literature 34(2), 171-182, https://doi.org /10.1177/0885412219831375.

Meuleman, L. (2015): Owl meets beehive: how impact assessment and governance relate. Impact Assessment and Project Appraisal 33(1), 4-15, https://doi.org /10.1080/14615517.2014.956436.

Ministry of Environment Finland (2009): Act on Environmental Impact Assessment Procedure, Unofficial 
translation. Retrieved August 24, 2017, https://www .finlex.fi/en/laki/kaannokset/1994/en19940468.pdf.

Ministry of Regional Development (2015): National document for Territorial Dimension.

Ministry of Regional Development (2018): Questionnaire among National Territorial Cohesion Contact Points.

Morrison-Saunders, A., Pope, J., Gunn, J. A. E., Bond, A., Retief, F. (2014): Strengthening impact assessment: a call for integration and focus. Impact Assessment and Project Appraisal 32(1), 2-8, https://doi.org/10.1080/14615517 .2013.872841.

Nijkamp, P., van Pelt, M. (1983): Spatial Impact analysis for developing countries. A framework and a case study, Serie Research Memoranda 0014, VU University Amsterdam, Faculty of Economics, Business Administration and Econometrics.

Nosek, Š. (2017): Territorial cohesion storylines in 2014-2020 Cohesion Policy. European PlanningSstudies 25(12), 2157-2174, https://doi.org/10.1080/09654313 .2017.1349079.

OECD (2010): Better regulation in Europe. Retrieved May 17, 2018, http://www.oecd.org/gov/regulatory-policy /betterregulationineuropebelgium.htm.

OECD (2011): Territorial Reviews Switzerland. Retrieved May 15, 2018, https://read.oecd-ilibrary.org/urban-rural -and-regional-development/oecd-territorial-reviews -switzerland-2011_9789264092723-en\#page1.

Othengrafen, F., Cornett, A. P. (2013): A Critical Assessment of the Added Value of Territorial Cohesion. Refereed article No. 53, October, 2013, European Journal of Spatial Development, https://archive.nordregio.se/en /News/A-Critical-Assessment-of-the-Added-Value-of -Territorial-Cohesion/index.html.

Perdicoúlis, A., Batista, L., Pinho, P. (2016): Logical chains in territorial impact assessment. Environmental Impact Assessment Review 57, 46-52, https://doi.org /10.1016/j.eiar.2015.11.006.
Polverari, L., Michie, R. (2011): Complementarity or conflict? The (in)coherence of Cohesion policy. European Policy Research Center, No. 78, University of Strathclyde 40 George Street Glasgow G1 1QE, http://www.eprc-strath. eu/public/dam/jcr:23283c26.../EPRP\%2078.pdf.

Raagmaa, G., Stead, D. (2015): Spatial Planning in the Baltic States: Impacts of European Policies IN Raagma, G., Stead, D. (eds.). Impacts of European Territorial Policies in the Baltic States. London: Routledge - Taylor \& Francis Group, 1-9.

Stutz, F.P., Warf, B. (2012): The World Economy: Geography, Business, Development. Hoboken, NJ: Pearson Education.

Szlachta J., Zaucha, J., Kormonicki, T. (2017): Polish development policy and its territorial dimension. In.: J. Bradley, J.Zaucha (eds.): Territorial Cohesion: A missing link between economic growth and welfare. Lessons from the Baltic tiger, Gdansk, 49-72.

Swiss Federal Council (2016): Sustainable Development Strategy 2016-2019. Retrieved April 23, 2018, https:// www.eda.admin.ch/agenda2030/en/home.html.

Tosics, I., Szemzö, H., Illés, D., Gerheis, A., Lalenis, K., Kalergis, D. (2010): National spatial planning policies and governance typology, www.plurel.org/images /D221.pdf.

Tscherning, K., König, H., Birthe, S., Helming, K., Sieber, S. (2007): Ex ante impact assessments (IA) in the European Commission: An overview. In: Helming, K., MartaPérez-Soba, M., Tabbush (eds.): Sustainability Impact Assessment of Land Use Changes. New York: Springer, 17-33, https://doi.org/10.1007/978-3-540-78648 $-1 \_3$.

Zonneveld, W., Waterhout, B. (2009): EU Territorial Impact Assessment: Under what Conditions? Final Report, Delft University of Technology, Delft, http://citeseerx.ist .psu.edu/viewdoc/download?doi=10.1.1.615.647\&rep $=$ rep $1 \&$ type $=$ pdf. 